UDC $577.112 .7+576.353+576.316+576.31$

\title{
Phospho-mTOR (Ser2481) colocalizes with condensed chromosomes during metaphase
}

\author{
V. R. Kosach, I. O. Tykhonkova, O. V. Cherednyk, V. V. Filonenko, A. I. Khoruzhenko \\ Institute of Molecular Biology and Genetics, NAS of Ukraine \\ 150, Akademika Zabolotnoho Str., Kyiv, Ukraine, 03680 \\ a.i.khoruzhenko@imbg.org.ua
}

\begin{abstract}
Aim. To study the subcellular localization of phospho-mTOR (Ser2481) in cultured cells of human cancer cell lines. Methods. Immunofluorescent analysis of phospho-mTOR (Ser2481) subcellular localization in cultured MCF-7 (human breast adenocarcinoma) and HepG2 (human liver carcinoma) cells. Results. For the first time phospho-mTOR (Ser2481) was detected as bright spots situated in the equatorial region of chromosomes and co-localized with condensed chromosomes during metaphase. Conclusions. In this study, we describe for the first time the co-localization of phospho-mTOR (Ser2481) and chromosomes of the metaphase plate in the MCF-7 and HepG2 cells. Our data support the hypothesis that phospho-mTOR (Ser2481) could act as a CPP (chromosomal passenger protein)-like kinase, which takes part in the regulation of mitosis progression.
\end{abstract}

K e y w or d s: mTOR, phospho-mTOR (Ser2481), mitosis, mTOR phosphorylation, metaphase.

\section{Introduction}

The mammalian target of rapamycin (mTOR) is a protein kinase involved in the regulation of cell growth and aging affecting numerous biosynthetic processes and cell metabolism [1]. Deregulation of mTOR is observed in many pathologies, including cancer, metabolic and neurodegenerative disorders [2,3].

Phosphorylation is one of the main posttranslational modifications that regulate kinase activity [4]. Usually, gradual modification of several phosphorylation sites is needed for full activation of protein kinases. Phosphorylation could also play an important role in the regulation of kinase subcellular localization $[5,6]$. mTOR kinase has four characterized phosphorylation sites: Ser1261 localized at the HEAT domain and three other sites Thr2446, Ser2448, Ser2481 - at regulatory domain, which is important for the mTOR kinase activity [7, 8]. Phosphorylation of serine 2481 is detected only in vertebrates and is known to be [an] autophosphorylation site. [9].
Previous studies showed that phospho-mTOR (Ser2481) is located at the midzone and cleavage furrow of the dividing cells. It was proposed that phospho-mTOR (Ser2481) could be a mitotic kinase [10]. However, the role of Ser2481 phosphorylation and targets of phospho-mTOR (Ser2481) during mitosis are unknown.

In this study we have shown for the first time that phospho-mTOR (Ser2481) localized as discrete foci at metaphase plate during mitosis in human cell lines MCF-7 and HepG2. Our data support the hypothesis proposed earlier that phospho-mTOR (Ser 2481) could act as a CPP (chromosomal passenger protein)like kinase during mitosis [11].

\section{Materials and Methods}

\section{Cell culture}

MCF-7 and HepG2 cells were cultivated in DMEM culture medium supplemented with $10 \%$ FCS, $4 \mathrm{mM}$ glutamine, 50 units $/ \mathrm{ml}$ penicillin, $50 \mu \mathrm{g} / \mathrm{ml}$

(C) 2016 V. R. Kosach et al.; Published by the Institute of Molecular Biology and Genetics, NAS of Ukraine on behalf of Biopolymers and Cell. This is an Open Access article distributed under the terms of the Creative Commons Attribution License (http://creativecommons.org/licenses/by/4.0/), which permits unrestricted reuse, distribution, and reproduction in any medium, provided the original work is properly cited 
streptomycin, medium was changed every third day. For immunofluorescent analysis the cells were seeded onto sterile glass coverslips and cultured for 2-3 days in 24 well plates.

\section{Immunofluorescent analysis}

Cultured MCF-7 or HepG2 cells were fixed with methanol for $10 \mathrm{~min}$ at room temperature. Thereafter, the cells were permeabilized with $0.2 \%$ Triton $\mathrm{X}-100$ in PBS for $10 \mathrm{~min}$ and incubated for $30 \mathrm{~min}$ at room temperature in $10 \mathrm{mM}$ cupric sulphate and $50 \mathrm{mM}$ ammonium acetate, $\mathrm{pH} 5.0$ to eliminate autofluorescence. Non-specific binding was blocked after incubation with $10 \% \mathrm{FCS}$ in PBS for $30 \mathrm{~min}$ at $37^{\circ} \mathrm{C}$. Between incubations the cells were washed with PBS three times for $3 \mathrm{~min}$.

Double immunofluorescent analysis was performed by addition of the primary antibody mix: rabbit $\bar{a}-$ phospho-mTOR (Ser2481) + mouse $\bar{a}-$ $\mathrm{Ki}-67, \overline{\mathrm{a}}-\mathrm{mTOR}$ antibodies for $1 \mathrm{~h}$ at $37^{\circ} \mathrm{C}$ in humidifying chamber.

The following dilutions of antibodies were used: rabbit polyclonal anti-phospho-mTOR (Ser2481) antibody (09-343 Merck Millipore, USA) 1:100, anti-Ki-67 antibody 1:1000 (generated and tested in our laboratory [12]), mouse ā- mTOR (clone F11, MABS14, Merck Millipore, USA) 1:50, rabbit ā-mTOR (N-19, sc-1549, Santa Cruz Biotechnology, USA) 1:50, rabbit ā-mTOR (7C10, \#2983, Cell Signaling Technology, USA) 1:50.

The secondary FITC conjugated anti-mouse antibodies, Texas Red conjugated anti-rabbit antibodies (Jackson ImmunoResearch Laboratories, Pennsylvania, USA) were applied as a mix in dilution 1:400 for $45 \mathrm{~min}$ at $37^{\circ} \mathrm{C}$ in humidifying chamber. In some cases DNA was counterstained with Hoechst 33342. Samples were washed and embedded into Mowiol medium (Sigma-Aldrich, St. Louis, USA) containing $2.5 \%$ DABCO (Sigma-Aldrich, St. Louis, USA).

All microscopy studies were performed using Leica DM 1000 fluorescent microscope (Leica Microsystems, Wetzlar, Germany) and Zeiss LSM 510 META microscope (Carl Zeiss Microscopy $\mathrm{GmbH}$, Jena, Germany).

\section{Results}

Double immunofluorescent analysis was performed on cell lines MCF-7 and HepG2 to study the peculiarities of the phospho-mTOR (Ser2481) subcellular localization. Antibody to the proliferating cell antigen Ki-67 was applied to visualize and distinct the different stages of cell cycle.

Interphase cells showed very low level of phospho-mTOR (Ser2481) fluorescence signal. In contrast, mitotic cells demonstrated bright staining, which had dramatically different subcellular localization of phospho-mTOR (Ser2481) during mitosis progression.

Phospho-mTOR (Ser2481) was detected at the midbody and the cleavage furrow in the anaphase and telophase (Fig. $1 \mathrm{~A}$, small arrow) as it was reported earlier [11]. However, we observed phosphomTOR (Ser2481) as bright dots among the arms of condensed chromosomes in metaphase for the first time (Fig. 1 A, long arrows). Double immunofluorescent analysis revealed phospho-mTOR (Ser2481) at the metaphase plates of HepG2 (Fig. 1 B) and MCF-7 (Fig. 1 C) cells.

At the same time the antibodies against different parts of non-phosphorylated mTOR molecule showed diffuse staining in the cytoplasm of mitotic cells (Fig. 2). Namely the antibodies against $\mathrm{N}$-terminal, C-terminal regions and central part of mTOR molecule were applied. No convincing reaction among the arms of condensed chromosomes was revealed. Only after chromosomes separation in anaphase, a bright positive reaction on mTOR was detected (data not shown). Phosphorylation of mTOR on Ser2481 could change the conformation of molecule that will make phospho-mTOR (Ser2481) inaccessible for the antibodies against non-phosphorylated mTOR.

\section{Discussion}

Serine 2481 is one of four characterized phosphosites of mTOR kinase. It is known to be autophosphorylated by mTOR. Serine 2481 localizes at the regulatory domain of the kinase and could be involved in the modulation of its activity $[8,9]$. 
In mammalian cells mTOR exists as a core enzyme of two different complexes: mTORC1 and mTORC2 $[13,14,15]$. Earlier studies showed that specific mTOR inhibitor rapamycin treatment did not affect Serine 2481 phosphorilation. So, it was hypothesized that phospho-mTOR (Ser2481) is a

$\boldsymbol{A}$

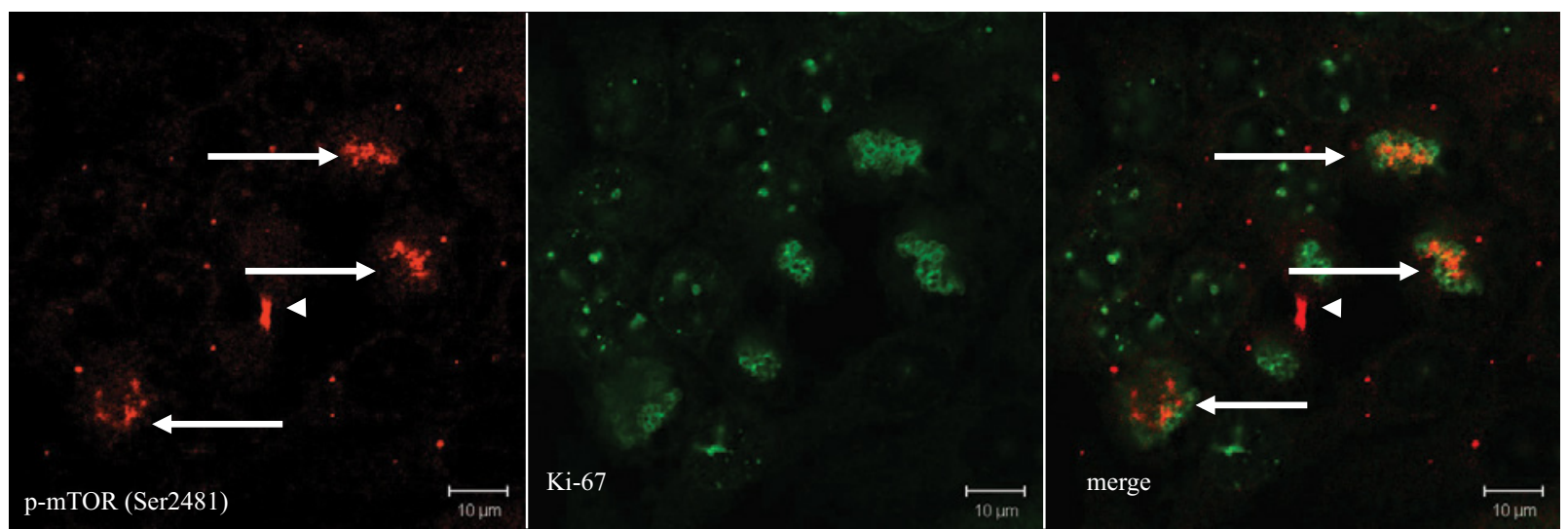

B
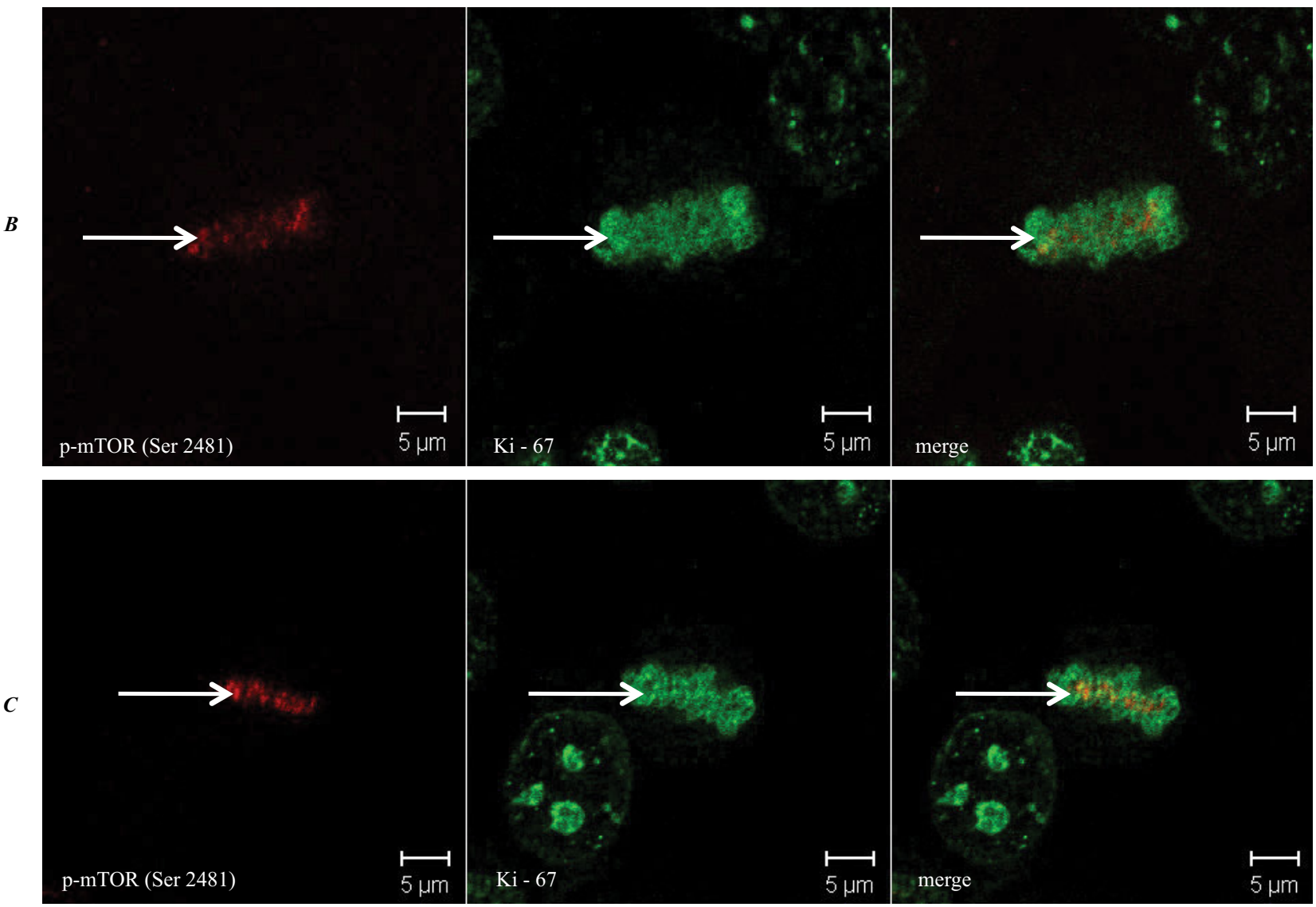

Fig. 1. $A$ - Immunofluorescent detection of phospho-mTOR (Ser2481) (red) and Ki-67 antigen (green) in HepG2 cells. $B$ - Immunofluorescent detection of phospho-mTOR (Ser2481) (red) and Ki-67 antigen (green) in metaphase plates of HepG2 cells. $C$ - Immunofluorescent detection of phospho-mTOR (Ser2481) (red) and Ki-67 antigen (green) in metaphase plates of MCF-7 cells. Cells in the metaphase are pointed with long arrows, the cleavage furrow in telophase are [is] pointed with small arrow. 
unique feature of mTORC2 [16]. However, further investigations demonstrated that the growth factors such as insulin stimulate the autophosphorylation of mTOR associated with both mTORC1 and mTORC2.
Also, it was revealed that phosphorylation of Ser 2481 in both complexes was sensitive to wortmannin, a phosphatidylinositol 3-kinase (PI3K) inhibitor. This finding indicates that insulin promotes

$\boldsymbol{A}$
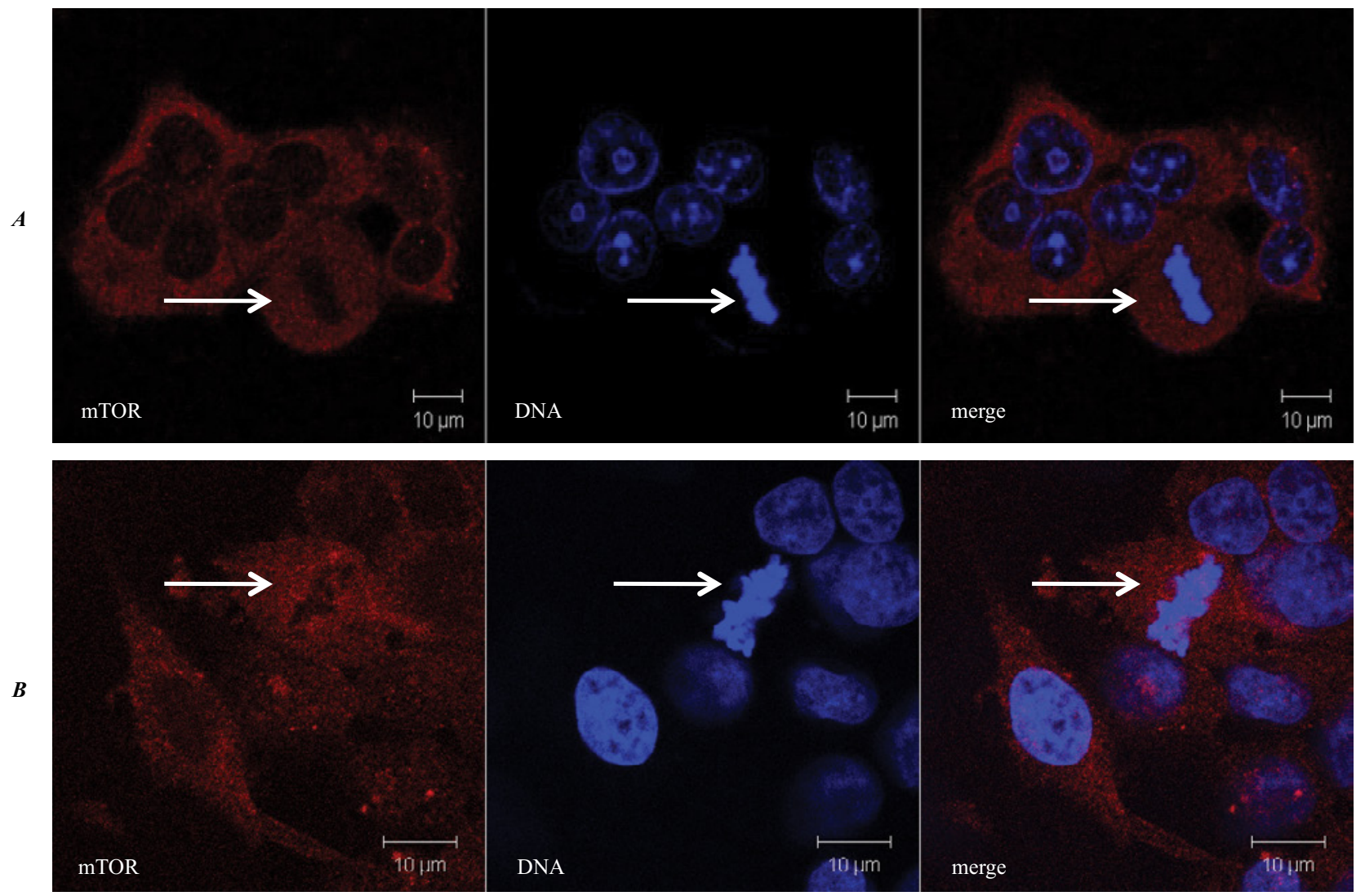

C

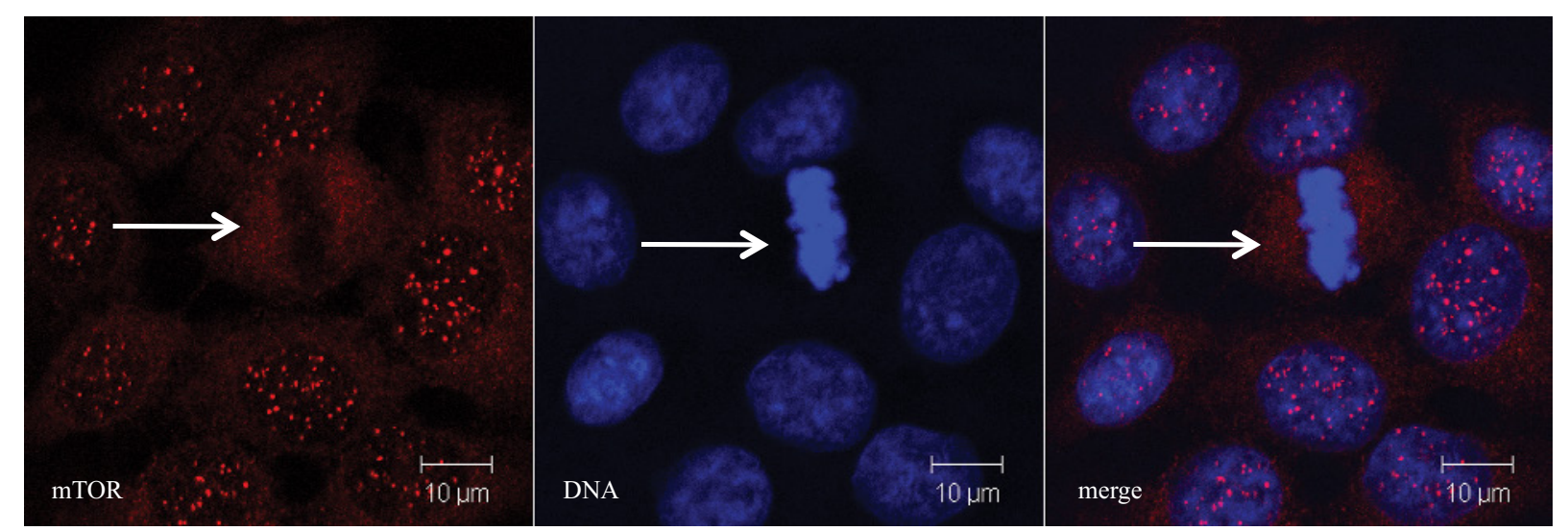

Fig. 2. Immunofluorescent detection of mTOR kinase in proliferating MCF-7 cells. $A$ - antibodies against central region of mTOR molecule (clone F11, Merck Millipore), $B$ - antibodies against C terminal part of mTOR (7C10, Cell Signaling Technology), $C-$ antibodies against N-terminus of mTOR kinase (N19, Santa Cruz Biotechnology). DNA was counterstained with Hoechst 33342. Cells in the metaphase are pointed with arrows. 
Ser2481 autophosphorylation in both complexes mTORC1 and mTORC2 [17].

Our immunofluorescent analysis revealed that mTOR phosphorylated at Ser2481 localized at the specific compartments of the mitotic cells and concentrated to the midzone and midbody during anaphase and telophase. The previous data showed that at cytokinesis mTOR, phosphorylated at Ser2481, appeared as a doublet at the apical ends of two daughter cells [10]. These data suggest that phosphomTOR (Ser2481) could play an important but yet unknown role in mitosis and cytokinesis regulation.

The recent studies have shown that phosphomTOR (Ser2481) co-localizes with chromosomal passenger proteins (CPPs) during cell cytokinesis [11]. It was revealed that phospho-mTOR (Ser2481) and CPPs INCENP and Aurora B overlaped during anaphase, telophase and cytokinesis. Therefore, it was hypothesized that phosphorylated mTOR may behave as a CPP-like protein at the spindle midzone and at the cleavage furrow [11]. Our findings strongly support this hypothesis. We also detected mTOR at the midbody and the cleavage furrow, but unlike the above data we demonstrated for the first time that phospho-mTOR (Ser2481) localized at the chromosomes of the metaphase plate in mitotic MCF-7 and HepG2 cells. The differences between our studies and previous work could be explained by possible discrepancies of the immunostaining protocols and technique of image acquisition.

It is known that CPPs localizes initially along chromosome arms, but progressively concentrates at inner centromeres through prometaphase and metaphase. There they regulate the chromosome structure and correction of kinetochore-microtubule attachment [18]. The discovered phospho-mTOR (Ser2481) localization at the metaphase plate shows the pattern similar to CPPs, but the real role and function of Ser2481 phosphorylation during mitosis are still unknown. It suggests that it participates in the formation of a niche for future midbody. From the other hand, our finding also raises a question about phospho-mTOR (Ser2481) co-localization with centromere proteins and its possible participa- tion in the chromosomal passenger complex functioning.

\section{REFERENCES}

1. Laplante M, Sabatini DM. mTOR signaling in growth control and disease. Cell. 2012;149(2):274-93.

2. Pópulo H, Lopes $J M$, Soares $P$. The mTOR signalling pathway in human cancer. Int J Mol Sci. 2012;13(2):1886-918.

3. Zoncu R, Efeyan A, Sabatini DM. mTOR: from growth signal integration to cancer, diabetes and ageing. Nat Rev Mol Cell Biol. 2011;12(1):21-35.

4. Groban ES, Narayanan A, Jacobson MP. Conformational changes in protein loops and helices induced by post-translational phosphorylation. PLoS Comput Biol. 2006;2(4):e32.

5. Edwards AS, Faux MC, Scott JD, Newton AC. Carboxylterminal phosphorylation regulates the function and subcellular localization of protein kinase C betaII. J Biol Chem. 1999;274(10):6461-8.

6. Maddika S, Ande SR, Wiechec E, Hansen LL, Wesselborg S, Los M. Akt-mediated phosphorylation of CDK2 regulates its dual role in cell cycle progression and apoptosis. $J$ Cell Sci. 2008;121(Pt 7):979-88.

7. Acosta-Jaquez HA, Keller JA, Foster KG, Ekim B, Soliman GA, Feener EP, Ballif BA, Fingar DC. Site-specific mTOR phosphorylation promotes mTORC1-mediated signaling and cell growth. Mol Cell Biol. 2009;29(15):430824.

8. Watanabe R, Wei L, Huang J. mTOR signaling, function, novel inhibitors, and therapeutic targets. $J$ Nucl Med. 2011;52(4):497-500.

9. Peterson RT, Beal PA, Comb MJ, Schreiber SL. FKBP12rapamycin-associated protein (FRAP) autophosphorylates at serine 2481 under translationally repressive conditions. J Biol Chem. 2000;275(10):7416-23.

10. Vazquez-Martin A, Oliveras-Ferraros C, Bernadó L, LópezBonet E, Menendez JA. The serine 2481-autophosphorylated form of mammalian Target Of Rapamycin (mTOR) is localized to midzone and midbody in dividing cancer cells. Biochem Biophys Res Commun. 2009;380(3):638-43.

11. Vazquez-Martin A, Sauri-Nadal T, Menendez OJ, OliverasFerraros C, Cufi S, Corominas-Faja B, López-Bonet E, Menendez JA. Ser2481-autophosphorylated mTOR colocalizes with chromosomal passenger proteins during mammalian cell cytokinesis. Cell Cycle. 2012;11(22):4211-21.

12. Khoruzhenko A, Kukharchuk V, Cherednyk O, Tykhonkova I, Ovcharenko G, Malanchuk O, Filonenko V. Monoclonal antibodies to Ki-67 protein suitable for immunohistochemical analysis. Hybridoma (Larchmt). 2010;29(4):301-4.

13. Hall MN, Tamanoi F. Structure, function and regulation of tor complexes from yeasts to mammals. Amsterdam: Academic Press, Elsevier. 2010:27-8. 
14. Filonenko $V V$. PI3K/mTOR/S6K signaling pathway - new players and new functional links. Biopolym Cell. 2013; 29(3):207-14.

15. Kosach VR, Cherednyk OV, Khoruzhenko AI. Characteristic of mTOR signaling and its involvement in the regulation of cell movements through remodeling the cytoskeleton architecture. Biopolym Cell. 2015; 31(1):5-14.

16. Copp J, Manning G, Hunter T. TORC-specific phosphorylation of mammalian target of rapamycin (mTOR): phosphoSer2481 is a marker for intact mTOR signaling complex 2 . Cancer Res. 2009;69(5):1821-7.

17. Soliman GA, Acosta-Jaquez HA, Dunlop EA, Ekim B, Maj NE, Tee AR, Fingar DC. mTOR Ser-2481 autophosphorylation monitors mTORC-specific catalytic activity and clarifies rapamycin mechanism of action. J Biol Chem. 2010;285(11):7866-79.

18. Carmena $M$, Wheelock $M$, Funabiki H, Earnshaw WC. The chromosomal passenger complex (CPC): from easy rider to the godfather of mitosis. Nat Rev Mol Cell Biol. 2012; 13(12):789-803.

\section{Phospho-mTOR (Ser2481) співлокалізусться 3 конденсованими хромосомами під час метафази}

В. Р. Косач, І. О. Тихонкова, О. В. Чередник, В. В. Філоненко, А. І. Хоруженко

Мета. Дослідити внутрішньоклітинну локалізацію phosphomTOR (Ser2481) в лініях ракових клітин людини. Методи. Подвійний імунофлуоресцентний аналіз. Культивовані клітини ліній MCF-7 (аденокарцинома молочної залози людини) i HepG2 (карцинома печінки людини). Результати. Вперше phospho-mTOR (Ser2481) був виявлений у вигляді яскравих точок, які розташовувались в екваторіальній області клітини та співлокалізувались 3 конденсованими хромосомами під час метафази. Висновки. У цьому дослідженні ми вперше описуємо співлокалізацію phospho-mTOR (Ser2481) і хромосом метафазної пластинки у клітинах ліній MCF-7 i HepG2. Наші дані підкріплюють гіпотезу, що phospho-mTOR (Ser2481) може виступати в якості СРР-кінази і брати участь у регуляції проходження мітозу.

Кл юч о в с сл в а: mTOR, phospho-mTOR (Ser2481), мітоз, фосфорилювання mTOR, метафаза.

\section{Phospho-mTOR (Ser2481) колокализируется с конденсированными хромосомами в метафазе}

В. Р. Косач, И. А. Тихонкова, О. В. Чередник, В. В. Филоненко, А. И. Хоруженко

Цель. Исследовать внутриклеточную локализацию phosphomTOR (Ser2481) в раковых клеточных линиях человека. Методы. Двойной иммунофлуоресцентный анализ. Культивированные клетки линий MCF-7 (аденокарцинома молочной железы человека) и HepG2 (карцинома печени человека). Результаты. Впервые phospho-mTOR (Ser2481) был обнаружен в виде ярких точек, которые располагались в экваториальной области клетки и колокализировались с конденсированными хромосомами во время метафазы. Выводы. В этом исследовании мы впервые описываем колокализацию phospho-mTOR (Ser2481) и хромосом метафазной пластинки в клетках линий MCF-7 и HepG2. Наши данные подкрепляют гипотезу, что phospho-mTOR (Ser2481) может выступать в качестве CРP-киназы и участвовать в регуляции прохождения митоза.

Ключевые сл ов а: mTOR, phospho-mTOR (Ser2481), митоз, фосфорилирование mTOR, метафаза.

Received 14.02.2016 